doi: $10.26529 /$ cepsj.509

\title{
Revisiting the European Teacher Education Area: The Transformation of Teacher Education Policies and Practices in Europe
}

VASILEIOS SYMEONIDIS ${ }^{1}$

$\approx$ Within the broader landscape of the European Higher Education Area, teacher education receives increasing significance as an academic field that contributes to the quality of the teaching labour force and consequently impacts student learning. This paper aims to explore the European Teacher Education Area (ETEA) by analysing to what extent and how mechanisms, processes, and key agents of Europeanisation, internal or external to the European Union (EU), influence the transformation of teacher education policies and practices in Europe. Transformation is understood in the context of Europeanisation, and emphasis of the analysis is placed on the process rather than the content of transforming teacher education in Europe. To this end, data have been collected through document review and expert interviews with European policy officials. As a result of qualitative content analysis, the data have been clustered and analysed according to the following categories, which mutually reinforce each other: (1) policy coordination; (2) cross-sectoral instruments; (3) evidence-based management; (4) the Bologna process; (5) educational programmes; and (6) stakeholder pressure. Findings provide a conceptual framework for mapping the ETEA as a complex policy ecosystem that includes vertical and horizontal procedures of Europeanisation. The EU has developed extensive capacities to influence teacher education in Europe and increasingly involves other sectors, such as employment, in this process.

Keywords: European teacher education area, teacher education policy, Europeanisation, policy mechanisms, key agents

1 Department of Teacher Education and School Research, University of Innsbruck, Austria; vasileios.symeonidis@uibk.ac.at. 


\section{Pregled evropskega prostora izobraževanja učiteljev: transformacije politik in praks izobraževanja učiteljev $\mathrm{v}$ Evropi}

VASILEIOS SYMEONIDIS

$\propto$ Znotraj širšega Evropskega visokošolskega prostora (European Higher Education Area) izobraževanje učiteljev pridobiva na pomembnosti kot področje, ki prispeva h kakovosti učiteljev, posledično pa vpliva tudi na učenje učencev. Prispevek raziskuje Evropski prostor izobraževanja učiteljev (European Teacher Education Area - ETEA), pri čemer analizira obseg in načine, na katere mehanizmi, procesi in ključni agenti evropeizacije znotraj ali zunaj Evropske unije (EU) vplivajo na transformacijo politik in praks izobraževanja učiteljev v Evropi. Transformacijo razumemo $\mathrm{v}$ kontekstu evropeizacije, $\mathrm{v}$ analizi pa poudarjamo procese in ne vsebin transformacij izobraževanja učiteljev v Evropi. S tem namenom smo podatke zbrali s pregledom dokumentov in $\mathrm{z}$ ekspertnimi intervjuji s funkcionarji s področja evropskih politik. Podatki, ki smo jih pridobili s kvalitativno vsebinsko analizo, so bili grupirani ter analizirani glede na naslednje kategorije, ki se medsebojno krepijo: 1) koordinacija politik; 2) medsektorski instrumenti; 3) na dokazih osnovano upravljanje; 4) bolonjski proces; 5) izobraževalni programi; 6) pritiski deležnikov. Ugotovitve ponujajo konceptualno ogrodje za mapiranje ETEA kot kompleksnega ekosistema politik, ki vključuje vertikalne in horizontalne procedure evropeizacije. EU je razvil obsežne kapacitete za vplivanje na izobraževanje $\mathrm{v}$ Evropi, pri čemer $\mathrm{v}$ ta proces vse bolj vključuje tudi druge sektorje, na primer zaposlovanje.

Ključne besede: Evropski prostor izobraževanja učiteljev, politike izobraževanja učiteljev, evropeizacija, mehanizmi politik, ključni agenti 


\section{Introduction}

Since the launch of the Lisbon Strategy in the year 2000, an accelerating process of Europeanisation of national policies related to teachers and teacher education has been witnessed (EDiTE, 2014), so that researchers are increasingly talking about a 'European teacher education policy community' (Hudson \& Zgaga, 2008), a 'European Teacher Education Area' (Gassner, Kerger, \& Schratz, 2010) and the 'European teacher' (Schratz, 2005, 2014). Although teacher education systems in Europe are firmly rooted in national histories and conditions (Kotthoff \& Denk, 2007), influenced by political culture (Louis \& Velzen, 2012), long-standing traditions, and resistance to theoretical and research-based arguments (Buchberger, Campos, Kallos, \& Stephenson, 200o), there are a number of common trends leading to convergence across countries (see Caena, 2014; Stéger, 2014a; Vidović \& Domović, 2013).

The reason behind this development in Europe is identified, on one hand, in accumulated research evidence indicating that students' performance is positively correlated with the quality of teachers (see Barber \& Mourshed, 2007; Hattie, 2009; OECD, 2005) and, on the other hand, in processes of harmonisation supported by the European Union (EU) under the objectives of a knowledge society (Domović \& Čuk, 2014) and human capital development (Moutsios, 2007). European policies and actions related to teachers and teacher education have received priority in the formulation of the EU's Education and Training (ET) 2010 work programme but became systematic by the middle of the 200os (Holdsworth, 2010). Various actors operating within the European education policy space, including the EU institutions, professional and policy networks, social partners and other stakeholders, promote policies and contribute to the knowledge base of effective teaching and teacher education (EDiTE, 2014). These actors also contribute to the emergence of transnational modes of governance, redefining the nature of and relationships between spaces, subjects, and coordination of governing education (Dale, 2009).

This paper aims to revisit the European Teacher Education Area (ETEA) by exploring to what extent and how mechanisms, processes, and key agents of Europeanisation, internal or external to the EU, influence the transformation of teacher education policies and practices in Europe. Transformation is understood in the context of Europeanisation, as a dynamic process that involves vertical and horizontal procedures unfolding over time and providing asymmetrical effects through complex mechanisms of interaction (Featherstone \& Kazamias, 2001). Depending on the level of 'misfit' between European and domestic processes (Börzel \& Risse, 2003, p. 58), those mechanisms of interaction 
can influence change in teacher education policies and practices reciprocally, meaning at both the level of the EU and of the Member States.

By using the term 'European', this paper refers to policies and initiatives developed within the framework of the EU, as well as to policies and initiatives related to the European continent at large. For example, the Lisbon Strategy was developed within the institutions of the EU, while the Bologna Process was initiated by European countries aiming to create a common European Higher Education Area (EHEA). Moreover, teacher education is examined more broadly, encompassing the whole continuum of teacher learning, namely Initial Teacher Education (ITE), induction, and Continuing Professional Development (CPD).

\section{Method}

As part of an ongoing study of Europeanisation in teacher education, this paper presents initial findings of qualitative data collected during October 2016 and February 2017, adopting the format of an empirically based report. The first phase of the study included document review of official EU policy documents, developed since the Lisbon Strategy in the year 2000, as well as websites and online materials of European institutions related to teachers and teacher education. Secondary data sources were also reviewed, including published academic texts and policy-related studies in the field of European teacher education.

To complement and qualify findings of the document review, a specific type of semi-structured interview was employed, namely expert interviews with European policy officials. In contrast to biographical interviews, expert interviews imply that 'the interviewees are of less interest as a (whole) person than their capacities as experts for a certain field of activity' (Flick, 2009, p. 165). In this sense, experts are included in this study not as single cases but as key agents representing a group. Experts are, thus, defined as those persons 'who are particularly competent as authorities on a certain matter of facts' (Beeke, as cited in Flick, 2009, p. 165).

Specifically, 13 expert interviews were held with representatives or consultants of the following institutions: European Commission, European Trade Union Committee for Education (ETUCE), Teacher Education Policy in Europe (TEPE) network and European Network on Teacher Education Policies (ENTEP). Interview questions were open-ended and tailored to the interview context and the interviewees, aiming to grasp the experts' specialised and practical knowledge related to mechanisms and processes shaping teacher and teacher education policies in Europe. All interviews were recorded with prior permission of the interviewees, transcribed verbatim and mailed back to the 
participants for final approval. For ethical reasons, the anonymity of the participants is ensured, and each interview is coded with the acronym European Policy Expert (EPE) and a number (e.g., Interview, EPE-1).

Documents and interview data were analysed using the method of qualitative content analysis (Mayring, 2014). In addition, the MAXQDA software was employed to help with coding and managing the amount of data. At first, theoretically derived aspects of analysis emerged from studying the literature on European governance in education. A flexible deductive approach was then used, in which some initial theoretical categories were applied to empirical data. However, the reading of documents and interview transcripts allowed for new themes to emerge inductively. After around twenty per cent of the material was coded, the categories were revised and reduced to some main categories, which were then reapplied to the full extent of the data. The specific categories are used to describe the mechanisms, processes and key agents of Europeanisation in European teacher education and will be presented in the following section.

\section{Mechanisms, processes and key agents in transforming European teacher education}

Exploring the landscape of European teacher education, we can identify a variety of mechanisms, processes and key agents, internal or external to the workings of the EU, that mutually reinforce each other towards shaping the process of Europeanisation in teacher education. For analytical purposes, these mechanisms, processes and key agents have been clustered according to their function in the following main categories: (1) policy coordination; (2) crosssectoral instruments; (3) evidence-based management; (4) the Bologna process; (5) educational programmes; and (6) stakeholder pressure. Several of these categories correspond to what Halász (2013) defined as governance and policy instruments which diffuse EU policies within the European education space and, thus, are also relevant when examining the development of teacher education policy in Europe. The following sections will describe how the specific mechanisms, processes and key agents influence European teacher education.

\section{Policy coordination}

Policy coordination in areas of 'soft' law, such as education and higher education, refers to governance mechanisms employed by EU institutions to align policies of the community in accordance to commonly agreed policy goals. Such mechanisms can include policy texts, the Open Method of Coordination (OMC), and presidencies. 
In teacher and teacher education policy, proposals can only be formulated as Communications of the European Commission, which may be approved by the Council of Ministers and consequently turn into Council Conclusions. Since the mid-2ooos, several Communications and Council Conclusions on teacher education and the professional development of teachers have been published. Specifically, the Rethinking Education Communication in 2012 is a milestone document, summarising ideas from several background documents, one of which is related to Supporting the Teaching Professions for Better Learning Outcomes (European Commission, 2012). Although regulations or directives cannot be issued in education, Directive 2013/55/EU regulates the recognition of teacher qualifications for free movement in the single market, indicating that the soft competence of the EU in education can be extended if it overlaps with other sectors, such as employment.

Since the Lisbon agenda in 2000, the launch of the OMC appears as the main policy mechanism that opened up the way for a degree of EU intervention in national education systems. The EU employs the OMC as a means of governing education developments by setting commonly agreed objectives, and through peer and informal pressures on the Member States to perform (Alexiadou, 2007). As part of the ET2O1O and ET2O20 work programmes, various working groups have been established to enhance cooperation between the Commission and the Member States. With regard to teacher education, the first working group on Improving the education of teachers and trainers was established in 2002 and with two subsequent reports proposed the development of teacher competence frameworks. The idea was realised with the Common European Principles for Teacher Competences and Qualifications (European Commission, 2005), a policy document which separated for the first time the area of teachers from the area of trainers, giving an impetus to policy cooperation in teacher education (Interview, EPE-3).

Following this, the Teachers and Trainers Cluster was formulated in 2005 and was later renamed as the Thematic Working Group on the Professional Development of Teachers in 2010, on School Policy in 2014, and on Schools in 2016. Comprised of Member State experts, the working groups aim at setting specific thematic goals for Peer Learning Activities (PLAs), a central tool of the OMC, and created a three-year time frame to increase the output orientation and efficiency of the work (Stéger, 2014a). Their results are published as guidance for policymakers, literature reviews, PLA reports, or virtual toolkits (European Commission, 2018a). The focus of those groups has mainly been on the ITE and CPD of teachers (Interview, EPE-2), while the following policy guidelines have been identified by interviewees of this study as most influential for national policy-making: (a) Supporting Teacher Competence Development (2013); (b) 
Supporting Teacher Educators (2013); and (c) Developing coherent and systemwide induction programmes for beginning teachers (2010) (Interview, EPE-4).

Presidencies provide opportunities in which the Member States can coordinate policy in a bottom-up way. Presidency priorities can bring to the attention of EU decision-makers particular challenges and good policy examples, which may result in specific Council Conclusions being accepted during the presidency period (Interview, EPE-6). It is worth noting here the example of the Irish presidency in 2013, for which the Commission was waiting before launching the policy package on supporting teacher educators (Interview, EPE-13), a priority topic for Ireland's education and training agenda ('Ireland's Presidency' 2013). Overall, most presidencies in the decade between 2005-2014 targeted the improvement in the quality of teacher education (Stéger, 2014a).

\section{Cross-sectoral instruments}

Policy instruments of sectors other than education play an increasingly significant role and influence developments in teacher education. Transferring policies from one sector to another is a common practice in the EU, which often launches initiatives in sectors for which the Member States are more receptive (Halász, 2013). In this respect, education is often linked to employment priorities, and thus, instruments applying to employment may well be influencing teacher education. Three cross-sectoral instruments can be identified as relevant: the European Qualifications Framework (EQF), financial resources, and the European semester.

EQF supports the Member States in comparing national qualifications systems by defining eight common European reference levels, described in learning outcomes: knowledge, skills, and responsibility and autonomy (European Commission, 2018b). Member States are, therefore, invited by the Recommendation of 23 April 2008 to reference their national qualifications frameworks to the EQF levels, facilitating this way occupational mobility and lifelong learning across Europe (European Parliament and Council of the EU, 2008). Naturally this development influences the field of teacher education which, depending on the level of education, can be referenced between EQF level 4 and EQF level 8, equivalent to postsecondary education diploma and doctoral degree studies. For example, early childhood education in Austria takes place at the postsecondary level and awards university entrance qualification (EQF 4 ), while university faculties of teacher education can award relevant doctorates (e.g. University of Innsbruck) (EQF 8).

Moreover, as a result of the EQF, the learning outcomes approach has had a significant impact on the different phases of teacher education by changing the way of writing curricula and qualification standards, and eventually the way of thinking about learning in both higher education and school education systems. 
Cedefop (2016, pp. 133-164) analysed the influence of learning outcomes in teacher education, arguing about the impact on the development of ITE curricula, on the collaboration between the different faculties and on the implementation of quality assurance at university and faculty levels. Learning outcomes aim at shifting the perspective from merely content knowledge towards skills and competences which would prepare individuals for the labour market (Interview, EPE-10).

To support the development of learning outcome approaches, some Member States have utilised European social funds (Cedefop, 2016), the second crosssectoral instrument examined here. Notably, the European Social Fund (ESF) has been extensively used by Member States to support the development of the ITE, CPD, and the competences of teachers and teacher educators (Stéger, 2014a). As an instrument of the Commission's Directorate General (DG) for Employment, ESF aims at supporting job growth and is distributed to Member States and regions to finance operational programmes which are commonly agreed between each Member State and the European Commission for the seven-year programme period (European Commission, 2016a). In an open public consultation of the ESF $2007-2013$, 55\% of respondents agreed, and 9\% disagreed that ESF support for individuals was successful in enhancing the skills of teachers (European Commission, 2016b). In addition to social and structural funds, innovation in the field of teacher education can be funded via Horizon 2020, the biggest EU research and innovation programme with a budget of approximately $€ 80$ billion for the period of 2014-2020 (European Commission, n.d.-a).

Another mechanism to bring education-related priorities under the umbrella of employment is the European semester, a coordination tool for economic and employment policies, which reports and monitors the contribution of education to growth and jobs. Each year, the Commission publishes Country Specific Recommendations (CSRs) for each Member State for budgetary, economic, and social policies, which the Council adopts at the end of June/early July, followed by policy advice that the Member States receive before they finalise their draft budgets for the upcoming year. Examining the 2016 CSRs, we can see that they are also aiming at improving quality in education and training. Among various recommendations emphasising the economic and employment relevance of education, with broader influence on teachers, there are concrete recommendations for the Czech Republic, Slovakia, and Latvia to improve the attractiveness of the teaching profession and the quality of teaching (European Commission, 2016c).

\section{Evidence-based management}

To achieve its policy goals in education, the Commission often employs the tool of knowledge and information spreading (Halász, 2013). Evidence-based 
policy making in education has been a flagship of the Commission since the launch of the OMC in the year 2000, manifested in the establishment of the thematic working groups, in defining benchmarks for monitoring effective practices between Member States, and in publishing statistical analyses for the challenges and progress in education and training systems (European Commission/EACEA/Eurydice, 2017, p. 5). In addition to the knowledge produced by the working groups, there are several European agents that contribute significantly to the evidence base for European and national policy development in teacher education. Specifically, EU networks and agencies, such as Eurydice and Cedefop, as well as Europe-wide associations, including the Association for Teacher Education in Europe (ATEE) and the European Educational Research Association (EERA), produce evidence and spread it in the European education space by means of publications, online resources, and public conferences.

Since 2002, Eurydice has published various reports focusing on teachers and teacher education, including the series The Teaching Profession in Europe (2002-2004), the Key Data on Teachers and School Leaders in Europe (20132015) and the Teachers' and School Heads' Salaries and Allowances in Europe (2012-2015). Further, the report Teaching Careers in Europe was published in 2018 (European Commission/EACEA/Eurydice, 2018), followed by the publication of a study on Boosting Teacher Quality - Pathways to Effective Policies that gathers evidence on policy measures to enhance teacher quality (European Commission, 2018c). Most of these reports analyse teacher education by comparing ITE programmes, induction and CPD, the supply and demand of teachers, recruitment and selection, the development of teacher competence frameworks, teacher mobility, as well as incentives and working conditions.

As a network of Member States with direct access to national ministries, Eurydice is in the optimal position to contextualise data, considering legislation and national specificities (Interview, EPE-7). However, due to its internal administrative structure, Eurydice cannot produce large-scale assessments and, thus, often relies on other international organisations, such as the Organisation for Economic Cooperation and Development (OECD), in terms of data collection. For example, the report The Teaching Profession in Europe (European Commission/EACEA/Eurydice, 2015) is based on secondary analysis of data from the 2013 OECD Teaching and Learning International Survey (TALIS). To this end, the Commission may also finance the participation of Member States in the TALIS survey (Interview, EPE-6).

Cedefop is another unit of the Commission that creates relevant knowledge for teachers and develops cross-sectoral tools influencing teacher education. Although focusing on European vocational and training policies, Cedefop 
is responsible for projects dealing with the implementation of the EQF and NQF, the learning-outcomes approach, the validation of non-formal and informal learning, as well as teachers and trainers' professional development (Cedefop, 2018). Particularly the European handbook on Defining, Writing and Applying Learning Outcomes (Cedefop, 2017) and the study Application of Learning Outcomes in Europe (Cedefop, 2016) provide concrete policy advice for shaping teacher education curricula. Since 2015, Cedefop has been transferred to the DG for Employment, another sign of the Commission's effort to have a more direct influence on education by connecting it to employment.

External to EU functioning, ATEE has operated as a non-profit European organisation since 1976 and addresses practitioners, including teachers and teacher educators. Aiming to bridge the gap between research and practice in teacher education, ATEE organises widely attended conferences, issues the European Journal of Teacher Education and sets up research and development communities around different themes (ATEE, 2015), including teacher education policy, and the professional development of teachers and of teacher educators. ATEE has contributed significantly to the European thinking of teacher education with studies examining the profile and competences of teacher educators (see Swennen \& Klink, 2009). Similarly, EERA with its Network 10 on teacher education research and the annual European Conference on Educational Research provides relevant knowledge platforms for teaching and learning.

\section{The Bologna Process}

A significant development with high impact on the structure of higher education, including teacher education, across Europe came with the Sorbonne Declaration in 1998, which led to the launch of the Bologna process one year later. The process proposed the creation of the EHEA through a common restructuring of higher education systems, based on a two-cycle structure of bachelors and masters degrees, in order to make them comparable and compatible. In 2003, a third cycle consisting of the doctorate was added. Although this process was intergovernmental in nature and was initiated outside the EU context, it cannot be understood independently of the EU higher education policy (Pépin, 2007). However, the fact that Bologna was developed outside the EU framework is judged as a reason for the considerable support it received, meaning that it was inclusive for non-EU countries and less bureaucratic (Corbett, 2011). Eventually, the process became more dependent on the Commission, both regarding financial support and policy advice (ibid.).

In the field of teacher education, many countries implemented Bologna reforms because of the need for professional renewal, for making teaching 
a more attractive career choice, and for improving the preparation of student teachers in subject methodology (Stéger, 2014b, p. 22). According to Iucu (2010, pp. 63-64), the main consequences of the Bologna process in teacher education relate to the structure of the teacher education systems, the introduction of the European Credit Transfer and Accumulation System (ECTS), the quality assurance process, and the application of the EQF, which was discussed previously. In addition to the EQF, it should also be mentioned here that the Framework for Qualifications of the European Higher Education Area (Bologna Working Group, 2005) has further contributed to the international recognition of qualifications in teacher education (Interview, EPE-13).

With regard to the structure of teacher education, the minimum total duration of ITE has been increased and adapted to the two-cycle model (European Commission/EACEA/Eurydice, 2015). Most countries in Europe require a bachelor degree for pre-primary and primary school teachers, while lower- and, mainly, upper-secondary school teachers are often expected to have a master degree (European Commission/EACEA/Eurydice, 2013). However, an analysis of ITE systems across Europe revealed that the increasing duration of ITE resulted in allocating more credits to subject matter, often at the expense of practice and the professional preparation of teachers (Stéger, 2014b).

The system of ECTS aims at improving mobility, recognition, and transferability both at ITE and CPD of teachers, supporting continuity between initial and continuous education and facilitating recognition of training periods conducted within community programmes (Iucu, 2010). Adopted as the national credit system in most EHEA countries, the ECTS is described as 'a paradigm shift from teacher-centred to student-centred higher education' (European Union, 2015, p. 14), along with the application of the learning outcomes approach.

The quality assurance process introduces the Standards and Guidelines for Quality Assurance in European Higher Education Area (ESG) which 'contribute to a common understanding of quality assurance for learning and teaching across borders and among all stakeholders' (ESG, 2015, p. 6). The ESG implies the need to introduce accountability mechanisms into ITE and CPD institutions, in terms of both an internal quality assurance by means of institutional policies and procedures, such as establishing fair and transparent processes for the recruitment and development of the teaching staff, as well as external quality assurance carried out by external experts and specialised agencies (ibid.).

At this point, mention should also be made of the TUNING project, launched in the year 2000 as a Socrates-Erasmus project with the aim 'to offer a concrete approach to implement the Bologna process at the level of higher education institutions and subject areas' (Tuning, 2008, p. 9). Tuning provides a 
methodology to design, implement and evaluate curricula for a variety of academic disciplines, including teacher education, in each of the Bologna cycles. Specifically, the publication Reference Points for the Design and Delivery of Degree Programmes in Education (Tuning, 2009) defines education as a subject that is divided into the scientific field 'education sciences' and the professional field 'teacher education' (ibid., p. 16). Thus, the publication provides cross-national evidence and guidelines for developing a common framework for teacher education in Europe.

Bologna proves to have had a considerable impact on the structure of teacher education systems (Stéger, 2014b), but a more profound influence in terms of changing institutional cultures towards learner-centred approaches is an ambiguous issue and requires more time. According to an interviewee, 'in many European countries, the Bologna reform was made in a very superficial way, [...] as a copy-paste of ready-made solutions from the centre into the local environments' (Interview, EPE-8). Without proper contextualisation, Bologna was seen in some institutions as 'cutting degrees in two pieces and modernising with upto-date literature' (Interview, EPE-8) and not always as an opportunity leading to the 'masterisation of the teaching profession' (Interview, EPE-3). Further, Bologna has often been employed by national or institutional policy actors as a way to promote their own political or institutional agendas (Interview, EPE-8).

\section{Educational Programmes}

Educational programmes are widely recognised as the mechanism with the highest impact on the professional development of teachers in Europe (European Commission/EACEA/Eurydice, 2015; Halász, 2013; Zgaga, 2013), although the resources spent here are lower than the ones invested in development interventions through the funding programmes described above. Educational programmes constitute a direct linkage between the education priorities of the EU and local institutions within Member States. Participation is voluntary, and individuals or organisations can apply directly for EU funding and support, resulting in a bottom-up Europeanisation that evades nationallevel policy processes and translations. Since the first generation of education programmes in 1986, the aim regarding teacher education was to promote the European dimension in initial and in-service training through professional mobility and institutional cooperation (European Council, 1988). To date, we can disaggregate physical and virtual mobility opportunities for teachers, supported by the Commission's Erasmus+ programme.

Advertised as one of the EU's 'most successful and iconic programmes' (European Commission, 2017a, p. 5), the Erasmus programme turned thirty in 2017 and celebrated a 40\% financial increase compared to its predecessors, 
accounting for $€ 14.7$ billion budget between 2014-2020 (European Commission, 2017 b). In terms of mobility exchanges, the programme envisages providing opportunities for 800,000 teachers and other staff to gain professional development abroad (ibid.). Within the programme's Key Action 1 - Learning mobility of individuals, teacher education has a very strong dimension (Interview, EPE-6).

However, the internationalisation of teacher education proves challenging compared to other areas of higher education (Zgaga, 2013), since evidence reveals the low number of teachers involved in mobility abroad. Only $27.4 \%$ of EU teachers have been abroad at least once for professional purposes, while the proportion of mobile teachers is even lower in several European education systems (European Commission/EACEA/Eurydice, 2015, p. 86). The specific results triggered the First European Conference on Internationalization of Teacher Education in 2017 which described as main reasons behind the low rate of teacher mobility the fact that several countries or institutions do not fully recognise credits and grades acquired abroad or they often require time-intensive compensatory measures (Worek \& Elsner, 2017).

In addition to physical mobility opportunities, the Commission has also developed information and technology support platforms, under the Erasmus+ Key Action 2 - Cooperation for innovation and the exchange of good practices. Specifically, the platforms eTwinning, School Education Gateway and Electronic Platform for Adult Learning in Europe provide virtual opportunities for teachers and teacher educators to exchange ideas and practices across Europe (European Commission, 2017a). The high take-up of such virtual and cost-efficient opportunities is evidenced in initiatives of some Member States to recognise them officially as professional development for teachers. For example, Greece and Italy introduced measures to recognise eTwinning as a relevant activity in support of teachers' career advancement (Interview, EPE-5).

\section{Stakeholder Pressure}

Among the various stakeholders influencing European teacher education policies and practices, global and European pressure groups play a highly significant role in providing consultation, in legitimising policies, and in mediating between the EU and national policymaking. Specifically, European social partners, international organisations, as well as networks contribute to educational cooperation in the area of teacher professional development.

European social partners are representatives of employers' organisations and trade unions, which are engaged in the European social dialogue, as stipulated by Article 154 and 155 of the Treaty on the functioning of the European Union (Eurofound, 2014). In the field of education, the Committee on European Social 
Dialogue is formed by the European Federation of Education Employers (EFEE) and the ETUCE, the regional organisation of Education International in Europe. However, as previously discussed, when education priorities fall under employment or social policies, then representatives from the industry can also play an influential role in setting the policy agenda (Interview, EPE-9). Further, the sectoral social dialogue in education is supported by the Commission's DG Employment.

Naturally, the social dialogue in education covers issues related to teachers and teacher education. Some of the key areas on which the Committee is currently focusing include: (a) how social partners can help improve teachers' skills and working conditions; (b) supporting teachers, with a focus on continuous professional learning and development; and (c) how the teaching profession can be made more attractive (European Commission, n.d.-b). According to an interviewee 'all policies related to teacher education are informally validated by the unions before publicly launched' (Interview, EPE-3), while another one refers to employers as 'having a subtle influence in a soft, sometimes hidden way, by conversations or organising conferences, promoting the linkage to the needs of the labour market' (Interview, EPE-4). In addition to consultation and lobbying, the social partners produce policy papers and research studies, such as the Teacher Education in Europe, an ETUCE policy paper published in 2008 and often cited in EU documents since then (see European Commission, 2012, 2013). Another technical report that shows the joint action between ETUCE and EFEE presents the results of a common survey on the recruitment and retention of teachers (ETUCE/EFEE, 2012).

The role of international organisations is also widely recognised as crucial in developing policy problems and setting new education policy agendas in Europe (Grek, 2010; Grek \& Lawn, 2009). The OECD is identified 'as a strong agent of Europeanisation' (Grek, 2010, p. 401) and an organisation with 'enormous influence on policy making' (Interview, EPE-7). As previously discussed, the European Commission works closely with the OECD, and their teacher policy agendas are overlapping. It is no coincidence that the EU's teacher policy emerged dynamically immediately following the OECD's study Teachers Matter in 2005 (Interview, EPE-13). However, the indirect influence of the OECD is judged as often having a greater impact (Interview, EPE-4).

Another influential organisation with a more global outreach is the World Bank which developed the 'Systems Approach for Better Education Results' (SABER) framework, a policy instrument targeting teachers and teacher education and applied in several countries, including some European ones. Among 10 areas suggested in SABER for teacher policy interventions, two are related to ITE and CPD, while eight policy goals, including the goal of 'preparing teachers 
with useful training and experience, are promoted as effective for improving the quality of the teacher labour force (World Bank, 2013, p. 24). A similar framework was produced by the UNESCO Teachers Task Force on Teachers for Education 2030 to support countries in developing evidence-based national teacher policy (UNESCO, 2015). Since 2018, the Teachers Task Force and the World Bank have been collaborating using SABER to 'see how data can benefit the development of teacher policies' (Teachers Task Force, 2018).

At this point, we should also include the work of the Council of Europe, which initiated the Pestalozzi Programme, an action supporting the professional development of teachers with a variety of teaching and training resources and the organisation of training events (Council of Europe, 2018a). Although the specific programme ceased operating in January 2018, a new capacity building programme is envisaged targeting Ministries of Education and teacher training institutions instead of practitioners (Council of Europe, 2018b).

Last but not least, European networks related to teacher education have shaped European policy and research discourses. One of the first initiatives funded by the European Commission was the SIGMA-European Universities' Network, commissioned to produce a report on European teacher training systems (Sander, Buchberger, Greaves, \& Kallos, 1996). The major policy impact of the SIGMA project can be seen in the establishment of the Thematic Network on Teacher Education in Europe (TNTEE) in 1996, which published the Green Paper on Teacher Education in Europe (Buchberger et al., 200o), the first policy paper on teacher education in Europe produced together with experts from European teacher education institutions (Hudson \& Zgaga, 2017). Building on the work of the TNTEE, TEPE emerged in 2006 as an academic network which organises annual conferences and publishes policy-related research in teacher education (ibid.).

Another relevant network that includes policy-makers and has a more direct link to the European Commission is ENTEP. Established in 2000, during the Portuguese presidency of the EU, ENTEP contributes with policy work to the development of the ETEA within the broader EHEA and promotes cooperation between Member States regarding teacher education policies (Gassner et al., 2010). Since the mid-20oos, the issue of what constitutes Europeanness in teachers' work has been raised within ENTEP, following the discussion paper What is a 'European teacher'? (Schratz, 2005). To promote the European dimension in teacher professionalism and address mobility problems and obstacles to entering $\mathrm{PhD}$ programmes, a consortium of five European universities and ENTEP, in the role of an advisory board, initiated the European Doctorate in Teacher Education (EDiTE) (Schratz, 2014). EDiTE received financial support from the European Commission, first as a project within the Lifelong Learning 
Programme (2012-2014), and then as a Horizon 2020 innovative training network (2015-2019), with the aim of developing into 'a leading European network for innovation in teacher education, accessible to academics, practitioners and policy makers' (EDiTE Website, 2015).

\section{Towards a European Teacher Education Area?}

The complex policy ecosystem of European teacher education consists of a multitude of key agents and mechanisms of interaction which complement or compete with each other in shaping the policies and practices of the specific field. Within this ecosystem, the EU has claimed a strategic role, acting either as the direct initiator or the subtle facilitator in several of the above-described initiatives. Figure 1 below illustrates the mechanisms, processes and key agents of Europeanisation that contribute to the emergence of the ETEA as a new governance space for teacher education in Europe. Using reciprocal interaction, the specific mechanisms, processes and key agents communicate and produce significant effects on policy formation and implementation, transforming the strictly nationally-bound conception of teacher education and resulting in a number of common trends across Europe.

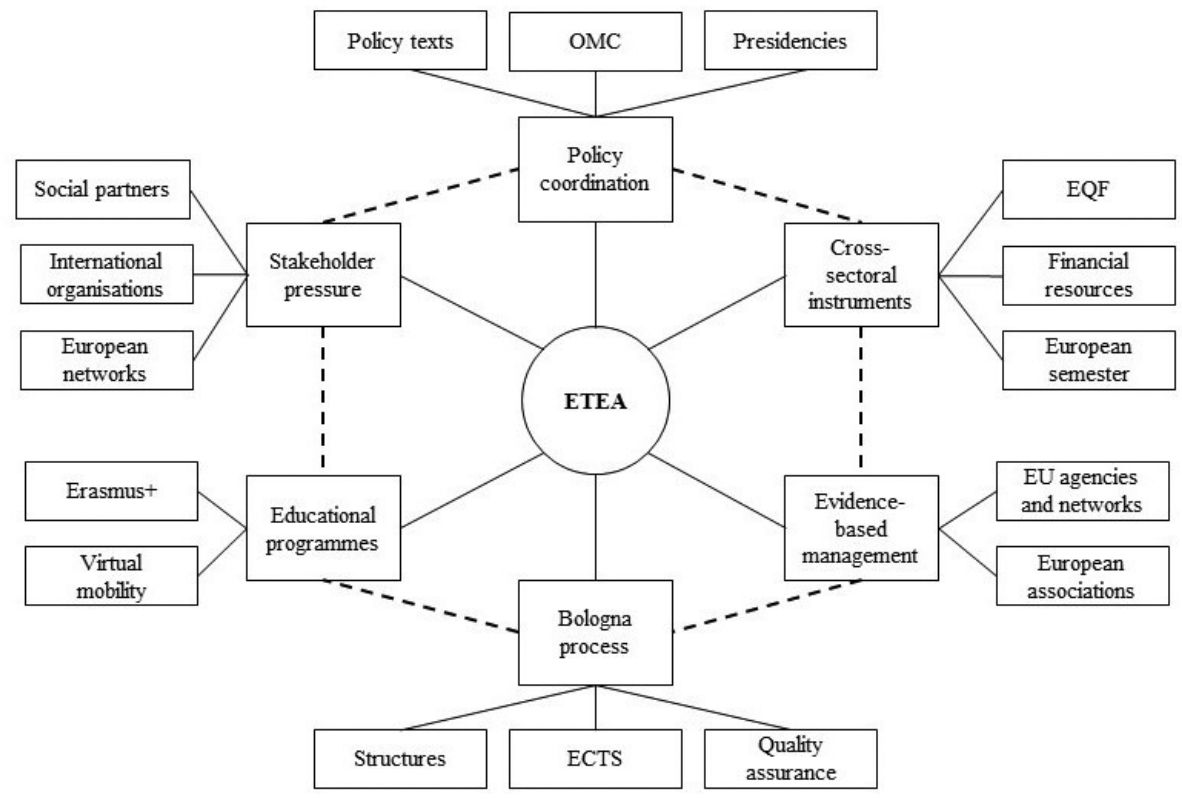

Figure 1. Mechanisms, processes and key agents of Europeanisation in the European Teacher Education Area (ETEA). 
From the perspective of Europeanisation, the emergence of the ETEA is the outcome of a 'circular approach' (Wach, 2017), which combines vertical and horizontal procedures of policy transfer. On the one hand, vertical procedures of downloading (from the European Community to Member States) and uploading (from Member States to the European Community) suggest a system of mutual adaptation between the European and domestic levels. Examples of downloading include the EU policy texts, cross-sectoral instruments, and evidence-based management, while uploading can occur through presidencies, transnational initiatives, such as the Bologna process, and stakeholder pressure. The OMC can be seen as a site of contestation between downloading and uploading policies, while educational programmes function as a direct linkage between the European and local institutions, often evading national level translations.

On the other hand, horizontal procedures imply a system of interaction at the domestic level, in which Europe might provide an impulse for policy change. External horizontal procedures involve policy learning among the Member States, while internal horizontal procedures involve policy learning among domestic actors. It is often at the domestic level that 'creative usages' of Europe take place, modifying actors' preferences and ways of doing things (Radaelli, 2004, p. 5). Horizontal procedures are facilitated by the OMC, benchmarking and the best practice examples, as well as by the exchange of experts in the form of working groups, policy or research networks and associations.

The emergence of the ETEA also confirms what Halász (2013) identified as future trends of the EU's education reform policies. One trend is the growing role of the EU in education policy, including teacher and teacher education policy, and its increasing capacity to influence Member States' educational developments. This occurs, for example, with a plethora of policy recommendations on improving the quality of teacher education, the influence of Bologna on the structure and content of teacher education programmes and the direct impact of mobility opportunities on teachers' professional development.

The second trend is the continuous possibility of other sectors to influence education developments. This becomes evident when teacher-related policies and initiatives fall under the priorities of the employment and social affairs sector, in which the EU has competences to provide arrangements within which Member States must coordinate policy. Often intentionally, instruments or agencies operating within the employment sector have an impact on teacher education (e.g., EQF and Cedefop's work) and may even monitor policy developments (e.g., European semester).

Although signs of convergence on what constitutes European teacher education are evident, teacher education still struggles to find its own way 
within the EHEA. The Europeanisation of the field has the potential to either exacerbate existing tensions or function as a remedy for historically rooted contradictions. In order to allow for new innovative solutions to emerge, the process of Europeanisation should enable teacher education systems to identify their own organisational patterns, considering that different countries may be in different stages of formulating and implementing teacher education policies.

\section{Acknowledgements}

The paper is part of the European Doctorate in Teacher Education (EDiTE) project that has received funding from the European Union's Horizon 2020 research and innovation programme under Marie Sklodowska-Curie grant agreement number 676452 .

\section{References}

Alexiadou, N. (2007). The Europeanisation of Education Policy: Researching changing governance and 'new' modes of coordination. Research in Comparative and International Education, 2(2), 102-116. ATEE. (2015). Statutes of association for teacher education in Europe. Retrieved from https://atee. education/who-we-are/

Barber, M., \& Mourshed, M. (2007). How the world's best-performing school systems come out on top. Analysis. New York, NY: McKinsey \& Company.

Bologna Working Group. (2005). A Framework for qualifications of the European higher education area. Retrieved from http://www.ecahe.eu/w/index.php/Framework_for_Qualifications_of_the_ European_Higher_Education_Area

Börzel, T., \& Risse, T. (2003). Conceptualising the domestic impact of Europe. In K. Featherstone \& C. Radaelli (Eds.), The politics of Europeanization (pp. 57-82). Oxford, UK: Oxford University Press.

Buchberger, F., Campos, B. P., Kallos, D., \& Stephenson, J. (Eds.) (2000). Green paper on teacher education in Europe. Umeå: University of Umeå.

Caena, F. (2014). Comparative glocal perspectives on European teacher education. European Journal of Teacher Education, 37(1), 106-122.

Cedefop. (2016). Application outcomes of learning across approaches Europe: A comparative study. Luxembourg: Publications Office of the European Union.

Cedefop. (2017). Defining, writing and applying learning outcomes: A European handbook. Luxembourg: Publications Office of the European Union.

Cedefop. (2018, January 18). Projects. Retrieved from http://www.cedefop.europa.eu/el/events-andprojects/projects

Corbett, A. (2011). Ping Pong: Competing leadership for reform in EU higher education 1998-2006. European Journal of Education, 46(1), 36-53. 
Council of Europe. (2018a). Closure of the Pestalozzi Programme since the end of 2017. Retrieved from https://www.coe.int/en/web/pestalozzi/-/capacity-building-in-education-at-the-council-of-europe Council of Europe. (2018b). Pestalozzi Programme. Retrieved from https://www.coe.int/en/web/ pestalozzi/home

Dale, R. (2009). Contexts, constraints and resources in the development of European education space and European education policy. In R. Dale \& S. Robertson (Eds.), Globalisation and Europeanisation in education (pp. 23-43). Oxford, UK: Symposium Books.

Domović, V., \& Čuk, M. P. (2014). Editorial - National vs. European trends within teacher education possibilities and challenges. CEPS Journal, 4(4), 5-10.

ETUCE/EFEE. (2012). Technical report of EFEE-ETUCE survey on recruitment and retention in the education sector. Retrieved from https://www.csee-etuce.org/images/Publications/VP-2011-001-0160_ Technical_Report_EN.pdf

ETUCE. (2008). Teacher education in Europe: An ETUCE policy paper. Brussels: ETUCE.

Eurofound. (2014). European social partners. Retrieved from https://www.eurofound.europa.eu/ observatories/eurwork/industrial-relations-dictionary/european-social-partners European Commission. (n.d.-a). What is Horizon 2020? Retrieved April 10, 2018, from https:// ec.europa.eu/programmes/horizon2020/en/what-horizon-2020

European Commission. (n.d.-b). Sectoral social dialogue - education. Retrieved April 7, 2018, from http://ec.europa.eu/social/main.jsp?catId=48o\&langId=en\&intPageId=1822\#top-page European Commission. (2005). Common European principles for teacher competences and qualifications. Retrieved from http://www.pef.uni-lj.si/bologna/dokumenti/eu-common-principles.pdf European Commission. (2012). Supporting the teaching professions for better learning outcomes. Accompanying document to the rethinking education: Investing in skills for better socio-economic outcomes. Retrieved from http://ec.europa.eu/dgs/education_culture/repository/education/policy/school/doc/ teachercomp_en.pdf

European Commission. (2013). Supporting teacher educators for better learning outcomes. Luxembourg: Publications Office of the European Union. Retrieved from http://ec.europa.eu/education/policy/ school/doc/support-teacher-educators_en.pdf

European Commission. (2016a). How the ESF works. Retrieved April 6, 2018, from http://ec.europa.eu/ esf $/$ main.jsp?catId=525\&langId=en

European Commission. (2016b). Ex-post evaluation of the 2007-2013 ESF Programmes. Retrieved from https://ec.europa.eu/info/sites/info/files/swd-2016-452-final_en.pdf

European Commission. (2016c). 2016 European semester: Country specific recommendations / Council recommendations. Retrieved April 6, 2018, from https:/ec.europa.eu/info/european-semester/ european-semester-timeline/eu-country-specific-recommendations/2016-european_en European Commission. (2017a). Erasmus+ annual report 2016. Retrieved from https://ec.europa.eu/ programmes/erasmus-plus/sites/erasmusplus2/files/annual-report-2016-stat-annex_en.pdf European Commission. (2017b). ERASMUS+ The EU programme for education, training, youth and sport (2014-2020). Retrieved from https://ec.europa.eu/programmes/erasmus-plus/sites/erasmusplus2/ 
files/gen-erasmusplus-factsheet-en-version11-2017-hd.pdf

European Commission. (2018a). ET 2020 working groups - European Commission. Retrieved April 6, 2018, from http://ec.europa.eu/education/policy/strategic-framework/expert-groups

European Commission. (2018b). How does the EQF work? Retrieved April 6, 2018, from https:// ec.europa.eu/ploteus/content/how-does-eqf-work

European Commission. (2018c). Boosting teacher quality - Pathways to effective policies. Luxembourg: Publications Office of the European Union.

European Commission/EACEA/Eurydice. (2015). The teaching profession in Europe: Practices, perceptions, and policies. Luxembourg: Publications Office of the European Union.

European Commission/EACEA/Eurydice. (2017). Support mechanisms for evidence-based policymaking in education. Eurydice report. Luxembourg: Publications Office of the European Union.

European Commission/EACEA/Eurydice. (2018). Teaching careers in Europe: Access, progress and support. Luxembourg: Publications Office of the European Union.

European Council. (1988). Resolution on the European dimension of education. Retrieved from http:// eur-lex.europa.eu/legal-content/HR/ALL/?uri=CELEX:41988Xo7o6(o1)

European Doctorate in Teacher Education (EDiTE). (2014). Teacher education and teacher education policies in the European Union. Retrieved from http://www.fmik.elte.hu/wp-content/uploads/2014/o6/ EDiTE_Budapest-conference_Issues-Paper_2014071.pdf

EDiTE Website. (2015). Retrieved from http://www.edite.eu/

European Parliament and Council of the European Union. (2008). Establishment of the European qualifications framework for lifelong learning. doi:10.2766/14352

European Parliament and Council of the European Union. (2013). Directive 2013/55/EU of the European parliament and of the Council. Retrieved from https://eur-lex.europa.eu/legal-content/EN/ $\mathrm{ALL} /$ ?uri=celex\%3A32013Loo55

European Union. (2015). ECTS users' guide. Luxembourg: Publications Office of the European Union. Featherstone, K., \& Kazamias, G. (Eds.) (2001). Europeanization and the southern periphery. London, UK, and New York, NY: Routledge.

Flick, U. (2009). An introduction to qualitative research (4th ed.). London, UK: Sage Publications. Gassner, O., Kerger, L., \& Schratz, M. (Eds.) (2010). The first ten years after Bologna. Bucureşti: Editura Universităţii din Bucureşti.

Grek, S. (2010). International organisations and the shared construction of policy 'problems': Problematisation and change in education governance in Europe. European Educational Research Journal, 9(3), 396-406.

Grek, S., \& Lawn, M. (2009). A short history of Europeanizing education. European Education, 41(1), $32-54$.

Halász, G. (2013). European Union: The strive for smart, sustainable and inclusive growth. In Yan Wang (Ed.), Education policy reform trends in G2o members (pp. 267-288). Berlin Heidelberg: Springer. Retrieved from http://halaszg.ofi.hu/download/G2O_EU_paper.htm Hattie, J. (2009). Visible learning meta-study. Oxon, UK: Routledge. 
Holdsworth, P. (2010). The European Union and teacher education. In O. Gassner, L. Kerger, \& M. Schratz (Eds.), The first ten years after Bologna (pp. 43-52). Bucureşti: Editura Universităţii din Bucureşti.

Howell, K. (2002). Developing conceptualizations of Europeanization and European integration: Mixing methodologies (ESRC Seminar Series / UACES Study Group on the Europeanization of British Politics). Retrieved from http://aei.pitt.edu/1720/

Hudson, B., \& Zgaga, P. (Eds.) (2008). Teacher education policy in Europe: A voice of higher education institutions. Umeå: University of Umeå.

Hudson, B., \& Zgaga, P. (2017). History, context and overview: Implications for teacher education policy, practice and future research. In B. Hudson (Ed.), Overcoming fragmentation in teacher education policy and practice (pp. 1-25). Cambridge, UK: Cambridge University Press.

Ireland's Presidency of the Council of the EU - Priorities. (2013). Retrieved April 6, 2018, from https://www.education.ie/en/Press-Events/Events/Ireland-s-Presidency-of-the-Council-of-the-EU/ Priorities.html

Iucu, R. (2010). Ten years after Bologna: On the way towards a European teacher education area. In O. Gassner, L. Kerger, \& M. Schratz (Eds.), The first ten years after Bologna (pp. 53-95). București: Editura Universităţii din Bucureşti.

Kotthoff, H.-G., \& Denk, R. (2007). Last past the post? Teacher education and the European higher education area. In H.-G. Kotthoff \& S. Moutsios (Eds.), Education policies in Europe economy, citizenship, diversity (pp. 115-130). Münster: Waxmann.

Louis, K. S., \& Velzen, B. van (Eds.). (2012). Educational policy in an international context: Political culture and its effects. New York, NY: Palgrave/McMillan.

Mayring, P. (2014). Qualitative content analysis: Theoretical foundation, basic procedures and software solution. Retrieved from http://nbn-resolving.de/urn:nbn:de:0168-ssoar-395173

Moutsios, S. (2007). The European Union and its education policy. In H.-G. Kotthoff \& S. Moutsios (Eds.), Education policies in Europe. Economy, citizenship, diversity. (pp. 15-25). Münster: Waxmann.

OECD. (2005). Teachers matter: Attracting, developing and retaining effective teachers. Paris: OECD Publishing.

Pépin, L. (2007). The history of EU cooperation in the field of education and training: How lifelong learning became a strategic objective. European Journal of Education, 42(1), 121-132.

Radaelli, C. M. (2004). Europeanisation: Solution or problem? European Integration Online Papers (EIoP), 8(16), 1-26. Retrieved from http://www.eiop.or.at/eiop/pdf/2004-016.pdf

Sander, T., Buchberger, F., Greaves, A., \& Kallos, D. (1996). Teacher education in Europe. Evaluation and perspectives. Osnabrück: Universität Osnabrück.

Schratz, M. (2005). What is a 'European Teacher'? A discussion paper European network on teacher education policies (ENTEP). Retrieved from http://www.pef.uni-lj.si/bologna/dokumenti/posvetschratz.pdf

Schratz, M. (2014). The European teacher: Transnational perspectives in teacher education policy and practice. CEPS Journal, 4(4), 11-27. 
Standards and guidelines for quality assurance in the European higher education area (ESG). (2015). Brussels. Retrieved from http://www.enqa.eu/index.php/home/esg/

Stéger, C. (2014a). Review and analysis of the EU teacher-related policies and activities. European Journal of Education, 49(3), 332-347.

Stéger, C. (2014b). State of play in teacher education in Hungary AFTER the Bologna reforms. Budapest: ELTE Eötvös Kiadó.

Swennen, A., \& Klink, M. van der. (2009). Becoming a teacher educator: Theory and practice for teacher educators. Berlin Heidelberg: Springer.

Teachers Task Force. (2018, February 22). SABER Country reports: Data collection for policy design. Retrieved from http://www.teachersforefa.unesco.org/v2/index.php/en/newss/item/6o1-saber-countryreports-data-collection-for-policy-design

Tuning. (2008). Universities' contribution to the Bologna process. An introduction (2nd ed.). Bilbao: Publicaciones de la Universidad de Deusto.

Tuning. (2009). Reference points for the design and delivery of degree programmes in education. Bilbao: Publicaciones de la Universidad de Deusto.

UNESCO. (2015). Teacher policy development guide: Summary. Paris: UNESCO.

Vidović, V. V., \& Domović, V. (2013). Teachers in Europe - Main trends, issues and challenges. Croatian Journal of Education, 15(3), 219-250.

Wach, K. (2017). Europeanisation: Its definition, research approaches and dimensions. In P. Stanek \& K. Wach (Eds.), Macro-, meso- and microeconomic dimensions of Europeanisation (pp. 15-31). Warszawa: PWN.

Worek, D., \& Elsner, D. (2017). First European conference on internationalization of teacher education. Unpublished manuscript.

World Bank. (2013). What matters most for teacher policies: A framework paper (SABER Working Paper Series No. Number 4). Retrieved from http://wbgfiles.worldbank.org/documents/hdn/ed/saber/ supporting_doc/Background/TCH/Framework_SABER-Teachers.pdf

Zgaga, P. (2013). The future of European teacher education in the heavy seas of higher education. Teacher Development, 17(3), 347-361.

\section{Biographical note}

VASILEIos Symeonidis is a researcher with the European Doctorate in Teacher Education (EDiTE) in the Department of Teacher Education and School Research at the University of Innsbruck, Austria. He holds a master's degree in international and comparative education from Stockholm University and a degree in primary school education from the Aristotle University of Thessaloniki. His research interests include comparative education, European and global trends in teacher education, education governance and reforms, critical pedagogy, and global citizenship education. 